\title{
EVALUATION OF COMPETITIVENESS FACTORS OF RURAL COMMUNITIES
}

\author{
Biruta ŠVAGŽDIENĖ, Department of Sports Management, Economics and Sociology, Faculty of Educology, Lithuanian Sports \\ University, Sporto str. 6, LT-44221 Kaunas district Lithuania. e-mail: biruta.svagzdiene@ 1su.lt \\ Dalia PERKUMIENÉ, Business and Rural Development Management Institute, Faculty of Economics and management, Aleksandras \\ Stulginskis University, Studentų 10, Akademija, Kaunas district Lithuania. e-mail: perkum@gmail.com (corresponding author)
}

\begin{abstract}
Competitiveness, which is inextricably linked to the notion of competition, remains the aim pursued by companies and countries because everyone wants to outsource others and, over time, enjoy the benefits.

A successfully competing community based by providing of services has more opportunities to attract and retain visitors, the same time implementing and meeting the needs of community members and ensuring community stability. With the rapid development of innovations and technologies, reveals the necessary to analyse the determinants of competitiveness.

The competitiveness of the rural area is reflected by factors such as investment attractiveness, living conditions, attractiveness for the population, geographical location, heritage, culture, the fostering of customs and traditions.

In order to assess the factors determining the competitiveness of rural communities, an investigation was organized. Methods chosen for the study: document analysis, SWOT and interviews.
\end{abstract}

Keywords: competitiveness, competitiveness factors, living conditions, rural communities.

\section{INTRODUCTION}

Competitiveness on the global market relates the ability to react quickly to market developments and maintain its position in it. From the creation and distribution of the value begins the idea of a competitive advantage (Beniušiene, Svirskienè, 2008). R. Činčikaite and R. Janeliunienè (2010) states that there is no unanimous opinion and definition of competitiveness.

The relevance and problem of competitiveness were analysed by the authors in various aspects, V. Snieška and J. Bruneckienè (2009), identify competitiveness as the main reason determining the rates and results of economic - social development of the region. V. Jusčius and V. Snieška (2008) emphasized the importance of corporate social responsibility in the process of forming competitive advantages. According to V. Navickas and A. Malakauskaite (2010), the ways and methods of evaluating the competitiveness are being analysed by communicating with clients and paying attention to the fact that the competitive advantage is given by distinguishing the quality in many branches of the industry (Beniušiene, Svirskienè, 2008).

Competitiveness can be gained due to influence of different factors. According to A. Liučvaitiene and K. Peleckis (2011), it is necessary to identify the factors that determine competitiveness for every business person who seeks to successfully develop a business and secure development opportunities. These, in turn, are usually divided into external and internal ones. However, in order to effectively assess competitiveness, both internal and external factors need to be considered in a complex way, because they are all interconnected and form a coherent framework.

With the growing interest of rural communities, it is appropriate to analyse the factors that determine their competitiveness. The factors that determine the competitiveness of rural communities have been examined episodically, therefore the topic is fundamentally new and relevant. A successfully competing community based by providing of services has more opportunities to attract and retain visitors, the same time implementing and meeting the needs of community members and ensuring community stability. With the rapid development of innovations and technologies, reveals the necessary to analyse the determinants of competitiveness. Different authors singled out different factors that determine competitiveness, therefore it is expedient to determine which factors determining competitiveness are most important and have the greatest influence on the competitiveness of rural communities; therefore, arises a problematic question: What are the factors that determine competitiveness?

The research problem - rural competitiveness is most often analysed considering to attractiveness of the rural area for the population. The rural competitiveness is a complex process, it needs to be analysed considering to the factors 
of competitiveness that are proposed to be integrated into the whole, in order to expose the whole rural competitiveness process.

The aim of the article - to evaluate the factors determining the competitiveness of rural communities.

Tasks:

1. To define the competitiveness and highlight the factors that determines it;

2. To reveal the competitiveness of the rural area and its factors;

3. To investigate the factors that determines the competitiveness of rural communities.

\section{THE PRESENTATION OF COMPETITIVENESS AND ITS DETERMINANTS}

Competitiveness - a widely used multi - dimensional concept which is including it factors determining and the environment analyzing (Valodkiené, Snieška, 2012). Competitiveness, which is inextricably linked to the notion of competition, remains the aim pursued by companies and countries because everyone wants to outsource others and, over time, enjoy the benefits. However, the term of competitiveness acquires a different definition itself depending on which author, scholar or institution / body uses and analyses it (Ramoniené, Lanskoronskis, 2011).

V. Navickas and A. Malakauskaite (2010) argue that competitiveness can be regarded as a complex economic category which has at least three levels: the macro - (which is reflects the economy of the country), the meso - (region, economy branch) and micro - (enterprise economy).

Competitiveness can be analysed in the research of objects and entities of different levels: a state, a union, a city, a country's economy, a company or an organization, a particular product or service. Thus, it can be argued that potential competitiveness depends of all these factors on the joint operation (Beniušienè, Svirskienè, 2008).

G. George and G. Manasis (2010) argue that competitiveness is an integral part of the economy, as the competitive process helps to distinguish itself in a competitive environment. Based on this position of authors it could be argued that in analyzing competitiveness it is necessary to analyse and the economic situation of the country, also to provide prospects for business development.

According to R. Čincikaitè and R. Janeliunienè (2010), competitiveness is understood not as a static, but a dynamic state, which is constantly need to maintain.

The results of the Kourdi (2010) research reveals that competency is a main factor in achieving competitive advantage. Competence is needed to evaluate what services are valuable and what capabilities are needed to prevent competitors from copying services. An accurate analysis of the company is necessary in order to distinguish the factors that determine competitiveness and the strategy implemented on the basis. It is also important to ensure customer loyalty and to ensure the quality of the services provided.

I. Beniušiene and G. Svirskienè (2008) note that scientific literature distinguishes a large number of factors influencing the competitiveness of industry (and the company). Usually they are divided into two major groups: (such a division is presented by both foreign authors: M. Porter, F. R. David, and both Lithuanian authors: I. Beniušienė, G. Svirskiené, V. Vitunskienė, J. Jusevičius and others) external and internal. Exterior environmental factors form the limits and opportunities that a company faces in a competitive environment. The external environment determines the internal environmental factors, i.e. the content of the company's operating environment. Meilienè and Snieška (2010) argue that the factors of competitiveness must be divided into prices and quality (by attributing the quality and good image of the goods).

V. Kalèdaite and E. Jasinskas (2013) came to the conclusion that the factors determining the competitiveness of enterprises were mostly divided into two main groups: internal and external environmental factors (Table 1).

Table 1. External and internal factors of competitiveness (Kaledaite, Jasinskas, 2013)

\begin{tabular}{|c|l|}
\hline \multicolumn{1}{|c|}{ External factors } & \multicolumn{1}{c|}{ Internal factors } \\
\hline $\begin{array}{l}\text { Macro - environment: political, economic, social, } \\
\text { technological, legal and demographic environment; }\end{array}$ & $\begin{array}{l}\text { Human Resources; knowledge and information, intellectual } \\
\text { copital; strategic goals and objectives; technology and }\end{array}$ \\
$\begin{array}{l}\text { Competitive enterprise environment: market demand; } \\
\text { innovation; the importance of fast response to customer needs, } \\
\text { entry barriers; market segmentation; substitutes; suppliers; } \\
\text { distribution channels. }\end{array}$ & $\begin{array}{l}\text { flexibility; product and / or service exclusivity, higher quality, } \\
\text { pricenterprise belonging to the network; international strategic } \\
\text { alliance or coalition; organizational training; productivity, low } \\
\text { company operating costs; the image. }\end{array}$ \\
\hline
\end{tabular}

The competitiveness of enterprises is more determined by internal factors than external factors of competitiveness. Internal factors are grouped into "soft" and "hard" factors and the environment, which links the first two groups into a single whole. The authors present a table that reflects external and internal factors of competitiveness.

A. Liučvaitienė and K. Peleckis (2011) argue that in order to assess competitiveness, the factors of competitiveness (Table 2) need to be considered in a complex way, because all of them are interrelated and form coherent system.

T.he determinants of competitiveness are interrelated and must be analysed in a general way, not excluding only a certain group of factors 
Table 2. The factors determines competitiveness (Liučvaitienè, Peleckis, 2011)

\begin{tabular}{|c|l|}
\hline Group of factors & \multicolumn{1}{c|}{ Factors } \\
\hline General factors & $\begin{array}{l}\text { Geopolitical situation of the country; legal system of the country; economic situation of the } \\
\text { country; economic and social policy of the state; demographic situation of the country; natural } \\
\text { and ecological state of the country. }\end{array}$ \\
\hline $\begin{array}{c}\text { Main features of the market } \\
\text { economy characteristics }\end{array}$ & $\begin{array}{l}\text { Regional differences; production price; financial support of the state; market capacity and } \\
\text { consumer solvency; tax system. }\end{array}$ \\
\hline $\begin{array}{c}\text { Operational infrastructure } \\
\text { factors }\end{array}$ & $\begin{array}{l}\text { Form of ownership; qualifications of employees; economic capacity of the entity; restructuring } \\
\text { of production structures and infrastructure; science research. }\end{array}$ \\
\hline
\end{tabular}

V. Navickas (2013) notes that many factors determine the competitiveness of the market, but the most important role to industrial competitiveness takes new products developing high added value, production, the introduction of new high technologies, the development of international cooperation (clusters), the application of modern management methods and e. business development. National scientific research programs also play an important role in the development of competitiveness. Such an author's opinion complements these factors that determine competitiveness.

V. Navickas and A. Malakauskaite (2010) notes that the process of evaluating competitiveness is a time consuming for financial and often human resource. From the degree of completeness and detail of the methodology directly depends not only on the accuracy of the evaluation results, the value, but also on the complexity of the evaluation process, the cost of the application of the methodology and the expediency. The main theoretical, or methodological, problems arising in the process of evaluating competitiveness are united, the lack of a clear conception of competitiveness the limitations of evaluation methodologies. At the practical level, there is encountered with a lack of time and financial resources and restrictions imposed by the availability of information. A. Liučvaitienè and K. Peleckis (2011) argue that in order to evaluate the possibilities of application of competitiveness models for evaluating competitiveness, it is necessary to evaluate the advantages and disadvantages of the competitiveness models and the possibilities of adaptation.

A couple of recent decades have been discussed in the international scientific debate on competitiveness issues. However, till these days, there is no unanimity view and a way of justifying the concept of competitiveness. Most of the world-wide competitive analysis methodologies developed by various organizations (the British National Bureau of Statistics; PriceWaterhouseCoopers; MNEX-The Metropolitan NewEconomyIndex; ECIEuropeanCompetitivenessIndex) emphasize the factors determine competitiveness in economic and social development (Charon, Vigilant, 2011).

The analysis of competitive factors is usually based on theories of inbound and outbound factors, economic and strategic factors, controlled and uncontrolled factors, structural and dynamic factors, internal and external factors (Bruneckienè, Kilijonienè, 2011).

J. Žukovskis (2011) and A. Aleksandravičius (2011) state that the main goal of the activities of rural communities in Lithuania is to encourage residents to try to improve their living conditions, to motivate them for self-education and cultural self-expression, to strengthen the manifestations of solidarity, to seek to prevent social exclusion tendencies to spread.

In order to increase the competitiveness of the state or the region, the involvement of decision-makers in the development of the territory must be considered as an important factor using their knowledge (Vidickienė, Melnikienė, 2014). Therefore, the competitiveness of rural areas is perceived as the ability of specific rural development characters to use the resources of the area, solving not only economic, but also social, environmental and territorial problems.

Rural competitiveness can be gained due to the influence of different factors, therefore general regularities and elements can only be used as ancillary measures for determining the competitive advantages of a certain area (Atkočiunienè, 2009; Bučinskas, 2014).

The competitiveness of the rural area does not arise from any general character of the desired. Rural areas cannot, as previously thought, be generally competitive. In fact, their competitiveness relates to the spatial flows that the rural area wants to attract, so there is no unified theoretical analysis of solutions for strengthening rural competitiveness. Various authors emphasize different factors determining rural competitiveness. Scientific literature often announces the importance of increasing the competitiveness of the rural area, but lacks reasonable methodologically models that integrates main determinants of rural competitiveness.

\section{RESEARCH ORGANIZATION AND RESULTS}

In order to assess the factors determining the competitiveness of rural communities, an investigation was organized. During the research, the deepening of the rural area is attractive, exclusive, with what problems are encountered, what opportunities and perspectives, in order to strengthen the competitiveness of the rural area, as well as possible threats were considered.

Methods chosen for the study: document analysis, SWOT and interviews.

The SWOT analysis was carried out on the basis of documentary analysis (documents of general EU legal acts related to the activities of rural communities, provisions of the Lithuanian Rural Development Program for 2014-2020, documents provided by the National Paying Agency under the Ministry of Agriculture, etc.), Statistics Department, data of rural community sites, as well as the analysis of scientific articles on this topic.

After analysing the SWOTs of rural communities, it was highlighted that the rural population has strong social ties, mutual support and cooperation, and old traditions and customs have been fostered. 
The study also found that most of the rural population is older, there is a lack of young and proactive younger people, which may result in a declining population in the future if sufficient attention is not paid to increasing the attractiveness of rural areas.

Table 3. SWOT Analysis of Humane Communities

\begin{tabular}{|c|c|}
\hline Strength & Weaknesses \\
\hline $\begin{array}{l}\text { Initiative, active and community - based. } \\
\text { The existence of strong social relationships. } \\
\text { EU funds are being absorbed through EU support. EU support } \\
\text { reaches nearly a quarter of Lithuania's annual budget annually. } \\
\text { A healthier lifestyle (such as active leisure) and the use of } \\
\text { healthier foods (self - grown organic fruits and vegetables). } \\
\text { Rural communities cooperate with each other. } \\
\text { Unique ideas and long - lasting traditions. A strong sense of } \\
\text { identity with the area, cherished customs and traditions. } \\
\text { Distinctness, heritage, culture. }\end{array}$ & $\begin{array}{l}\text { Lack of people's entrepreneurship: insufficient ability to apply } \\
\text { and improve skills and technological experience, to deploy new } \\
\text { technologies, to optimize the use of financial resources. } \\
\text { Lack of young and proactive younger people; } \\
\text { Community economic, social, environmental and other } \\
\text { problems and their solutions, for example, the spread of harmful } \\
\text { habits, health care problems: residents of far - off medical } \\
\text { institutions, limited labour market; } \\
\text { The variety of services provided is not sufficiently developed. } \\
\text { There are no projects that could attract additional funds. } \\
\text { Organization of child and youth employment. } \\
\text { The activities of community centres only partially ensure the } \\
\text { interests of the population. }\end{array}$ \\
\hline & \\
\hline $\begin{array}{l}\text { Concentration of people into joint activities, development of } \\
\text { their community. } \\
\text { Strengthening people's self - help and cultural expressions; } \\
\text { Cooperation with various organizations (for example, crafts). } \\
\text { Activate service marketing. } \\
\text { Increasing the motivation of the population and staff. } \\
\text { Dissemination of information and training (for example, on the } \\
\text { absorption and use of EU funds, computer literacy, etc.). } \\
\text { Organization of cultural and sporting events. } \\
\text { Activation of community centres; } \\
\text { Search and attraction of local and foreign investments; } \\
\text { Implementation of IT technologies and promotion of their use. } \\
\text { Infrastructure improvement. }\end{array}$ & $\begin{array}{l}\text { Changing the procedure for government financing may reduce } \\
\text { infrastructure development. } \\
\text { The chosen strategic direction may be inappropriate and } \\
\text { alternative alternatives may present challenges in the future. } \\
\text { Lack of continuity of goals and plans, lack of interest of the } \\
\text { population. } \\
\text { Social exclusion. } \\
\text { Failure to comply with decisions. } \\
\text { Total economic situation of the country. } \\
\text { Government policy on rural communities. }\end{array}$ \\
\hline
\end{tabular}

The study found that rural communities lacked attention to the economic, social, environmental and other problems of the community, the diversity of services provided was not sufficiently developed, projects were not developed that could attract additional funds, organizing the employment of children and youth, ensuring the interests and needs of children and young people, insufficient attention to the dissemination of information and marketing, then we should seek to update the information on the websites of rural community portals.

There is a need for a continuous interpretation of the needs of the members of the rural community and one of the solutions is to analyse the need and identify the priority needs. By acquiring marketing processes, new opportunities for provision of services and attraction of funds can be discovered. The successful activities of the rural community in order to make better decisions are inseparable from the systematic approach to information management, which is related to the use of information systems. The methods of developing information systems and their software enable the integration of business, information processing and software components and thus execute the gap between the services provided by the programs and the actual needs of the computerized organization.

In the semi - structured interview method ${ }^{1}$, the representatives of rural communities in Kaunas region ${ }^{2}$, related to the organization of the activities of rural communities, were interviewed. Interviewees were asked what the rural area is unique about, what determines the attractiveness and distinctness of the rural area, as well as what problems and problems are most often encountered.

The study found that the main problems of rural communities are rural unemployment, lack of social exclusion, lack of health care facilities or excessive distances from rural areas, as well as the reduction and integration of formal and non - formal education, the number of schools, and the younger age groups members who raise children in towns or emigrate.

Intervenants emphasized that in rural communities there are strong social relations between members of the community who interact and collaborate with each other, organize common celebrations, take part in these activities of the church, cultural centres. As an important factor emphasizing the specialty of the rural communities, they identified the living environment, which leads to a healthier way of life, as well as the fostering of tradition traditions. During the interviews, there were also opportunities for the absorption of EU funds, but it turned out that the population lacked information and leaders who could initiate and lead the projects.

\footnotetext{
${ }^{1}$ This method sought to verify and refine the results of the SWOT analysis.

${ }^{2}$ It was questioned 20 persons from the different Kaunas region subdistricts. The main purpose of this interview was to investigate their opinion about the attractiveness and distinctness of the rural area.
} 
In assessing the factors determining the competitiveness of rural communities, it should be noted that the main determinants of competitiveness, which are revealed through SWOT analysis and internal interviewing: clients, human resources, internal processes and external: demand, government policies and technologies.

The research determines the model of factors that determine competitiveness, which reflects the factors that determine the competitiveness of rural communities (Fig. 1). The model is based on the results of the study.

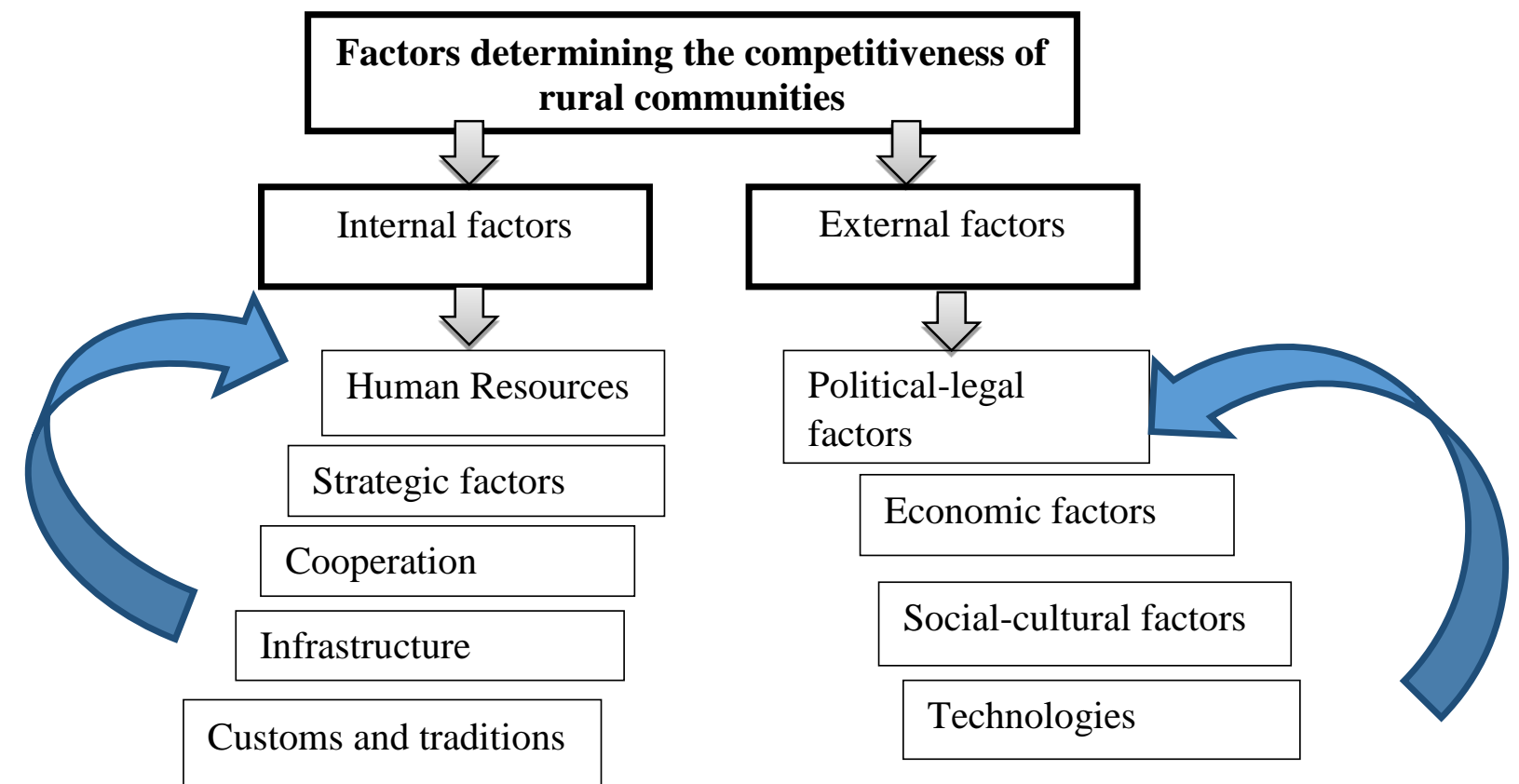

Figure 1. Model of factors contributing to competitiveness

Internal factors that are keys to the competitiveness of rural communities are human resources, cooperation, customs and traditions, infrastructures and strategies. Not only comprehensive strategic planning methodological research is needed in order to formulate effective strategies for competing rural communities, but also effective regional economic - social analysis and strategic planning measures based on the principles of complexity, reliability, comparability and simplicity.

External factors that influence the competitiveness of rural areas are government policies and decisions, economic factors that determine quality of life, and focus on technologies that help improve the quality of life of the population. External factors include social and cultural factors.

All of the above - mentioned factors affecting the competitiveness of rural communities are dynamic and, at the same time, individual. Both internal and external factors are interrelated. Knowledge of these factors and their impact can facilitate understanding of the attitudes of rural community members towards solving community economic, social, environmental and other problems, and formulate the right strategies.

\section{CONCLUSIONS}

1. Competitiveness can be defined as a process that helps to respond to changes in a competitive environment and to stand out in a competitive struggle. Competitiveness factors are divided into external and internal factors. External factors are political and economic factors, demand, technology, infrastructure. Internal - human resources, internal processes, finance.

2. The competitiveness of the rural area is reflected by factors such as investment attractiveness, living conditions, attractiveness for the population, geographical location, heritage, culture, the fostering of customs and traditions.

3. The competitiveness of rural areas is based on and perceived as the creation and maintenance of the maximum value added of the various actors in the rural area, thus strengthening the various community relationships, trust or assistance between the sectors, while also contributing to the overall coherence of the development of the rural area.

4. Having assessed the factors determining the competitiveness of rural communities, it has been pointed out that factors determining the internal competitiveness are: human resources, living environment, strategies, cooperation, infrastructure, customs and traditions, social relations among members of the community, opportunities for absorption of EU funds, social exclusion. The external determinants of the competitiveness of rural communities are government policies, socio-cultural, economic factors and technologies.

\section{REFERENCES}

1. Aleksandravičius, A., Žukovskis, J. 2011. Kaimo bendruomenių raida ir jų veiklos tikslai: siekiant darnumo visuomenèje. Management theory and studies for rural business and infrastructure development, Vol. 1 (25), pp.7-16. [In Lithuanian] 
2. Atkočiūnienè, V. 2009. Kaimo vietovių konkurencingumą lemiantys veiksniai. Ekonomika ir vadyba: aktualijos ir perspektyvos, Vol. 3 (16), pp. 39-49. [In Lithuanian]

3. Beniušienė, I., Svirskienė, G. 2008. Konkurencingumas: Teorinis aspektas. Ekonomika ir vadyba: aktualijos ir perspektyvos, Vol. 4(13), pp. 32-40. [In Lithuanian]

4. Bučinskas, A. 2014. Darnaus vystymosi problemos Lietuvos kaimo raidos procese. Tiltai, No. 3, pp. 17-34. [In Lithuanian]

5. Bruneckienè, J.; Kilijonienè, A. 2011, Lietuvos regionų konkurencingumo klasterinè analizè. Management theory and studines for rural business and infrastructure development, Vol. 1 (25), pp. 19-25. [In Lithuanian]

6. Charon, J. M., Vigilant, L. G. 2011. Social Problems: Readings with Four Questions, Wadsworth Publishing, Minnesota.

7. Činčikaitė, R., Janeliūnienė, R. 2010. Imonių konkurencingumas žinių ekonomikos sąlygomis. Business, management and education, pp. 1-9. [In Lithuanian]

8. George, G., Manasis, G. 2010. Researching the Factors that are affecting the Competitiveness of the Manufacturing Enterprises of Region Attica in Greece. International Research Journal of Finance and Economics, Vol. 1(54), pp. 7-18.

9. Jusčius, V., Snieška, V. 2008. Influence of corporate social responsibility on competitive abilities of corporations'. Engineering Economics, No. 3, pp. 34-44.

10. Kalėdaitè, V., Jasinskas, E. 2013. Viešbučių konkurencingumą lemiantys veiksniai Kauno mieste. Mokslas ir praktika: aktualijos ir perspektyvos, pp. $74-82$.

11. Kourdi, J. 2010. Verslo strategijos. Alma Littera,Vilnius. [In Lithuanian]

12. Liučvaitienè, A., Peleckis, K. 2011a. Šiuolaikinio verslo konkurencingumo formavimo ir vertinimo teoriniai modeliai ir jų taikymo galimybès. Contemporary issues in business, management education, No. 14, pp. 195-210. [In Lithuanian]

13. Liučvaitienè, A., Peleckis, K. 2011b. Konkurencinio pranašumo formavimas globalioje rinkoje: teorinès prielaidos ir vertinimo galimybès. Contemporary issues in business, management education, No. 14, pp. 181-194. [In Lithuanian]

14. Meilienė, E., Snieška, V. 2010. Lietuvos pramonės konkurencingumo veiksniai eksporto politikos nuostatose. Viešoji politika ir administravimas-Public Policy and Administration, Vol. 31, pp. 58-63. [In Lithuanian]

15. Navickas, V. 2013. Ekonomikos konkurencingumo valdymas. Mokslo darbų apžvalga. Edukologija, Vilnius. [In Lithuanian]

16. Navickas, V., Malakauskaitè, A. 2010. Konkurencingumo vertinimo metodologinès problemos ir ribotumas. Verslas: teorija ir praktika, No. 11(1), pp. 5-11. [In Lithuanian]

17. Ramonienè, L., Lanskoronskis, M. 2011. Reflection of higher education aspects in the conception of national competitiveness. Baltic Journal of Management, Vol. 1 (6), pp. 124-139. https://doi.org/10.1108/17465261111100932

18. Snieška, V., Bruneckienė, J. 2009. Measurement of Lithuanian Regions by Regional Competitiveness Inde. Engineering Economics, No. 1 (61), pp. 45-57.

19. Valodkienè, G., Snieška, V. 2012. Tarptautinis konkurencingumas ir ji lemiantys veiksniai ekonomikos nuosmukio laikotarpiu. Economic and Management, No. 17(2), pp. 602-608. [In Lithuanian]

20. Vidickienè, D., Melnikienè, R. 2014. Kaimo politikos evoliucija: monografija. Lietuvos agrarinès ekonomikos institutas, Vilnius. [In Lithuanian] 